\title{
Çanakkale İli Karamenderes Alt Havzası Tașkın Ovasının Çeltik Yetiștiriciliğine Uygunluğunun Arazi Değerlendirmesi
}

\author{
Timuçin EVEREST ${ }^{1 *}$
}

\author{
Hasan ÖZCAN²
}

\author{
'Gıda, Tarım ve Hayvancılık Bakanlığı, Çanakkale-Ezine İıçe Müdürlüğü, Çanakkale \\ ${ }^{2}$ Çanakkale Onsekiz Mart Üniversitesi, Ziraat Fakültesi, Toprak Bilimi ve Bitki Besleme Bölümü, Çanakkale
}

\author{
*Sorumlu yazar e-posta (Corresponding author e-mail) : timucineverest@gmail.com \\ Geliș tarihi (Received) : 06.05.2016 \\ Kabul tarihi (Accepted): 17.10.2016
}

\section{Öz}

Bu çalıșma, Karamenderes havzası tașkın ovasının alt havzasını olușturan Kumkale ovasında gerçekleștirilmiștir. Daha önce detaylı toprak etüt ve haritalama çalıșması yapılan 3545 da alanda, arazilerin çeltik yetiștiriciliğine uygunluğu değerlendirilmiștir. Çalıșmada, Coğrafi Bilgi Sistemi (CBS) kullanılarak olușturulan veri tabanında her bir çeltik parselinin arazi değerlendirme haritası üzerindeki konumu sorgulanmıș ve (FAO, 1977)'de belirtilen arazi uygunluk sınıfları içindeki yeri değerlendirilmiștir. (FAO, 1977)'nin ön gördüğü prensiplere göre çalıșma alanına toprak özellikleri (üst toprak tekstürü, alt toprak tekstürü, derinlik, kireç içeriği, vertik özellik, drenaj koșulları, yüzey tașılığı, tuzluluk, organik madde içeriği ve $\mathrm{pH}$ ), topoğrafya, bölge jeolojisi, iklim özellikleri ve sosyo-ekonomik verilere göre bir değerlendirme çalıșması yapılmıștır. Çalıșma sonucunda çeltik tarımı yapılan arazilerinin \% 38,89'unun S1 (çok uygun), \% 26, 16'sının S3 (az uygun) ve \% 34,45' inin N1 (geçici uygun değil) sınıfında olduğu belirlenmiștir. Çalıșma alanında uygun olmayan bölgelerde yapılan üretim çeltik parsellerinde ve çevresinde taban suyu yükselmesi, diğer arazilere istenmeyen su hareketi, su kalitesindeki olumsuz etkiler, üretim maliyetinin artması ve üreticiler arası bazı sosyolojik problemlere neden olmaktadır. İncelenen alandaki ruhsatlandırmalar sürdürülebilir bir tarım açısından çok önemli sorunlar olușturacak potansiyele sahiptir.

Anahtar Kelimeler: Arazi değerlendirme, coğrafi bilgi sistemi, çeltik, uygunluk

\section{Land Evaluation for Rice Cultivation of Çanakkale Karamenderes Sub-basin Flood Plain}

\begin{abstract}
This study was conducted in Kumkale plain where is sub-basin of Karamenderes flood plain basin. In the study, land evaluation work for rice land use type was carried out where covering (3545 da) area detailed soil survey and mapping work had done previously. In the study a database was created by using GIS techniques. Each rice parcel's location was detected on the land evaluation map and these parcels' location was determined on the suitability class for (FAO, 1977). An evaluation work carried out with the principles of (FAO, 1977) in the study area (soil texture of topsoil and subsoil, depth, lime content, vertic properties, drainage conditions, surface stony, salinity, organic matter content and $\mathrm{pH}$ ), topography, geology of region, climate conditions and socio-economic data's. As the result of study it was determined that $38.89 \%$ of rice lands were S1 (highly suitable), $26.6 \%$ of S3 (marginally suitable) and $34.45 \% \mathrm{~N} 1$ (currently not suitable). Production which is made not suitable areas cause problems in the study area. This problems can be listed as increasing ground water in rice parcels and their around.
\end{abstract}


Unaccepted water movement to other lands, negative effects in water quality, increasing the production cost, having sociological problems with each other of farmers. In the study area parcels which were permitted have a potential of very big problems for sustainable agriculture.

Key Words: Land evaluation, geographical information system, rice, suitability

\section{Gíriș}

Tarımsal üretimin sürdürülebilir olarak devamını sağlamak için toprakların yeteneklerine göre kullanılması gerekmektedir. Yetenekleri ve özellikleri doğrultusunda kullanılmayan topraklar zamanla olumlu özelliklerini kaybederek temel üretkenlik fonksiyonlarını yerine getiremez hale gelirler. Ülkemizde arazi kullanım türlerinin tercin edilmesinde genel olarak bir planlama bulunmamaktadır. Üreticiler günün koșulları, alıșkanlıklar, yatkınlıklar, gelir-gider durumları v.b. bazı sosyolojik olguları kendi çerçevesinde değerlendirerek arazi kullanım türlerini belirlemektedirler.

Pirinç dünya nüfusunun yarısına yakının temel gıdasını olușturmaktadır (Kondo vd., 2000). Yapılan projeksiyonlara göre küresel nüfus artıșına denk gelen pirinç talebin karșılanması için 2030 yılına kadar çeltik üretiminin \% 25 civarında arttırılması gerekmektedir (Seck vd., 2012). 2015 yılı Türkiye İstatistik Kurumu (TÜIK) verileri incelendiğinde çeltik Türkiye genelinde toplam 115.856 ha alanda yetiștirilmiștir. Türkiye tahı üretiminin (toplam 65.523 bin ton) \% 9,8'ini tek bașına çeltik ürünü karșılamıștır (6400 bin ton). Ülkemiz çeltik ekilișinin $\%$ 9,53'ü (110519 da) Çanakkale ilinde gerçekleștirilmiș, Ezine ilçesinde ise 5315 da alanda yetiștirilmiștir (TÜIK, 2015).

Çeltik yetiștiriciliğinin uygunluğu ile ilgili kaynaklar incelendiğinde; Dengiz (2013) Çankırı, Kızılırmak'ta çeltik tarımı yapılan toprakların arazi değerlendirmesini yaptığı çalıșmasında çeltik arazi istekleri ve mevcut arazilerin özelliklerini toprak kalite indeksi ile modellemiș ve arazileri uygun olmayandan çok uygun olana kadar dört farklı șekilde sınıflamıștır. Çalıșmada CBS teknikleri kullanılarak bu dört sınıf haritalandırılmıștır. Samanta vd., (2011) topografik bir katman (eğim, bakı), toprak özelliklerini (tekstür, su tutma kapasitesi, derinlik, pH, azot, fosfor ve potasyum) içeren bașka bir katman ve iklim katmanı olmak üzere üç ayrı katman kullanarak bir model geliștirmișlerdir. Modeli CBS ve uzaktan algılama teknikleri kullanarak değerlendiren araștırmacılar çeltik arazi uygunluğunu belirlemișlerdir. Çalıșma sonucunda arazi uygunluğu beș kategoriye ayrılmıș ve çeltik arazilerinin \% 4, 1 çok uygun, \% 21,3 orta-iyi, \% 44 orta, \% 25,7 orta-uygun olmayan ve \%5' inin uygun olmayan alanlardan oluștuğunu ortaya koymușlardır. Saygın (2013) Samsun, Bafra'da gerçekleștirdiği detaylı toprak etüt ve haritalama çalıșması doğrultusunda ilgili haritalama birimlerine göre bir modelleme yapmıș ve CBS aracılığı ile uygunluk analizi gerçekleștirmiștir. Yapılan değerlendirmeler neticesinde arazilerin \% 60' ının çeltik tarımı için yüksek derecede ve orta uygun, \% 20 ' sinin az uygun ve diğer \% 20' sinin ise uygun olmayan alanlarda olduğunu belirlemiștir.

Peșkircioğlu vd., (2013) Türkiye genelinde makro ölçekte genel bir arazi uygunluk haritası üzerine çalıșmıșlar ve çeltik bitkisinin temel iklim ve yükselti istekleri doğrultusunda, CBS tekniklerini kullanarak bir harita üretmișlerdir. Üretilen bu harita ile çeltik yetiștiriciliğine uygun olan havzaları ülke ölçeğinde sunmușlardır. Maddahi vd., (2014) İran Mazandaran'da (FAO, 1977)' de ön görülen değerlendirme yöntemini kullanarak çeltik arazi uygunluğunu değerlendirmiștir. Tüm arazi örtüsünün incelendiği çalıșmada çeltik arazilerinin $\%$ 6,83' ünün çok uygun, \% 25,80' inin orta uygun, \% 36,0' ının az uygun ve 16,91' inin uygun olmayan alanlardan oluștuğunu belirlemișlerdir. Özșahin (2016) Tekirdağ, Hayrabolu deresi havzasında gerçekleștirdiği çalıșmasında Ekinci (1990)' ın yapmıș olduğu toprak etüt ve haritalama çalıșması verilerini altık olarak kullanmıș ve Dengiz (2013) modelinin ön gördüğü kriterlere göre arazi uygunluğunu belirlemiștir. Yapılan bu çalıșma sonucunda Hayrabolu deresi havzası arazilerinin \% 74,1 oranında çeltik tarımına uygun alanlardan oluștuğu tespit edilmiștir.

Ezine ilçesinde çeltik arazi kullanım türü Ezine Merkez, Balıkı-Kızılköy ovası ve Karamenderes ovasında bulunmaktadır (Anonim, 2015). Karamenderes ovasının Ezine bölümünde çeltik yetiștiriciliği flüviyal araziler üzerinde yapılmaktadır (Everest ve Özcan, 2015). 
Karamenderes Nehri Havzası Çanakkale ili Kazdağı-Bayramiç-Ezine-Kumkale hattını takiben Marmara denizine boșalımlıdır. Havza üst (KazdağıBayramiç bölgesi), orta (Ezine bölümü) ve alt havza (Kumkale Ovası)' dan olușmaktadır. Havza içinde Ezine ve Kumkale Ova' larında bazı bölümlerde çeltik tarımı yapılmaktadır. Celtik tarımı yapılan arazilerin uygunlukları farklılık göstermektedir. Optimal ve sürdürülebilir bir tarımsal üretim için arazilerin arazi kullanım türlerine uygunluklarının belirlenmesi gerekmektedir. Bu çalıșmada, alt havzanın güney bölümünde (Kumkale Ovası membasında) 3545 da alanda arazi değerlendirme çalıșması yapılarak alanın çeltik yetiștiriciliğine uygunluğu belirlenmeye çalıșılmıștır.

\section{MATERYAL VE YÖNTEM}

\section{Materyal}

Çalıșma alanı $39^{\circ} 56^{\prime} 42^{\prime \prime}$ - $39^{\circ} 55^{\prime} 13^{\prime \prime}$ enlemleri ve $26^{\circ} 10^{\prime} 48^{\prime \prime}-26^{\circ} 13^{\prime} 48^{\prime \prime}$ boylamları arasında kalan 3545 da alan kaplayan Karamenderes ovası Ezine bölümü arazilerini içermektedir (Șekil 1).

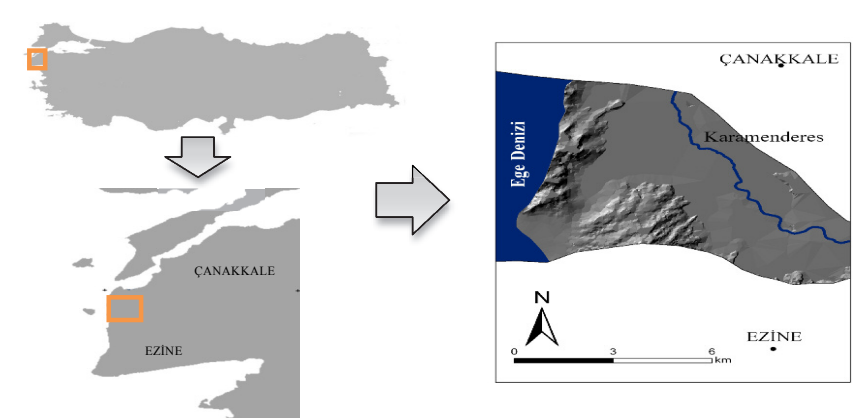

Șekil 1. Çallșma alanı

Figure 1. Study area

Çalıșma alanı ve çevresindeki jeolojik yapı kuvaterner alüvyonlardan olușmaktadır (Kayan, 2000). Çeltik yetiștiriciliği tașkın ovalarında yoğunluklu olarak Entisol ordosunun Typic Ustifluvents alt grubu, Vertisol ordosunun Typic Haplusterts ve Ustic Endoaquents alt grubu üzerinde bulunan topraklarda yapılmaktadır (Everest, 2015). Çalıșma alanı Marmara havzası içinde yer almaktadır. Marmara ile Ege denizlerinin etkisinde kalan havzanın iklimi Akdeniz iklim tipine büyük benzerlik göstermektedir (Atalay, 1991). Celtik arazileri deniz seviyesinden 5 metre ile 15 metre yükseklikler arasında bulunmaktadır. Çalıșma alanında çeltik bitkisinin yanı sıra, serin iklim tahılları, fiğ, ayçiçeği, domates, biber, kavun, karpuz, yonca, tohumluk ve silajlık mısır ürünleri yoğun olarak yetiștirilmektedir. Çalıșmada temel kartografik materyal olarak (Everest, 2015)'in gerçekleștirmiș olduğu 1/10.000 ölçekli detaylı toprak etüt haritalama verileri kullanıımıștır. Çalıșmada ArcGIS 9.1 CBS yazılımı kullanılımıștır. Çeltik arazilerinin parsel bazındaki verileri 1/1000 ölçekli kadastro paftaları kullanılarak elde edilmiștir. Çeltik bitkisinin ekolojik istekleri incelendiğinde çimlenme ve fide devresinde $18-35^{\circ} \mathrm{C}$ arasını arzuladığı, kritik sıcaklık değerinin ise $12-15{ }^{\circ} \mathrm{C}$ olduğu görülmekte, su tutma kapasitesi yüksek, pH 5, 5-7,5 değerine sahip toprakları tercih ettiği bilinmektedir (Sürek, 2002).

\section{Yöntem}

Çalıșmanın akıș diyagramı Șekil 2' de sunulmuștur. Celtik tarımı yapılan Mahmudiye, Üvecik, Yeniköy ve Pınarbașı köylerinde bulunan toplam 225 çeltik parselinin her birinin koordinat değeri GPS ile alınarak kaydedilmiș ve kadastro haritasının üzerine ișlenmiștir. Çalıșmada, Everest (2015) tarafından üretilmiș olan detaylı toprak etüt haritalama verileri kullanılımıștır. Bu verilerden çeltik arazi kullanım türü için üretilmiș olan arazi değerlendirme haritası altlık harita olarak kullanılmıștır. Kadastral verilerin temel toprak haritasının üzerine çakıștırabilmesi için 1/1000 ölçekli kadastro paftaları ArcGIS 9.1 yazılımında sayısallaștırılırmıș ve temel toprak haritasının üzerine konumlandırılarak parsel bazında bir veri tabanı olușturulmuștur. Bu olușturulan veri tabanı ile kadastral verisi sayısallaștırılan çeltik parselleri, arazi değerlendirme haritası üzerine yerleștirilmiș ve hangi çeltik parselinin hangi uygunluk sınıfı içinde kaldığı tespit edilmiștir.

Arazi değerlendirme çalıșmasında çeltik parsellerinin bulunduğu alanların üst toprak tekstürü, alt toprak tekstürü, eğim değeri, derinlik verisi, kireç içeriği, vertik özelliği, drenaj koșulları, yüzey tașlılığı, tuzluluk içeriği, organik madde içeriği ve $\mathrm{pH}$ değerleri sayısallaștırılmıștır. Parsellerin tespit edilmesi ve alan verilerin elde edilmesi esnasında üreticiler ve konu uzmanları ile görüșülmüștür. Bu bilgiler doğrultusunda bütün arazi karakteristikleri optimum düzeydeyken oransal beklenen ürün miktarı (OBÜ) 1.00 olarak kabul edilmiștir. Arazi karakteristiklerinin kısıtlayııı etmenlerin etkisiyle optimum düzeyden uzaklașmasıyla 1.00'dan azalan değerlere göre ÖBÜ değerleri olușturulmuș ve 0.00-1.00 arası değișen OBÜ endeksleri hesaplanmıștır. Her bir parametrenin etkisi için olușturulan ÖBÜ 


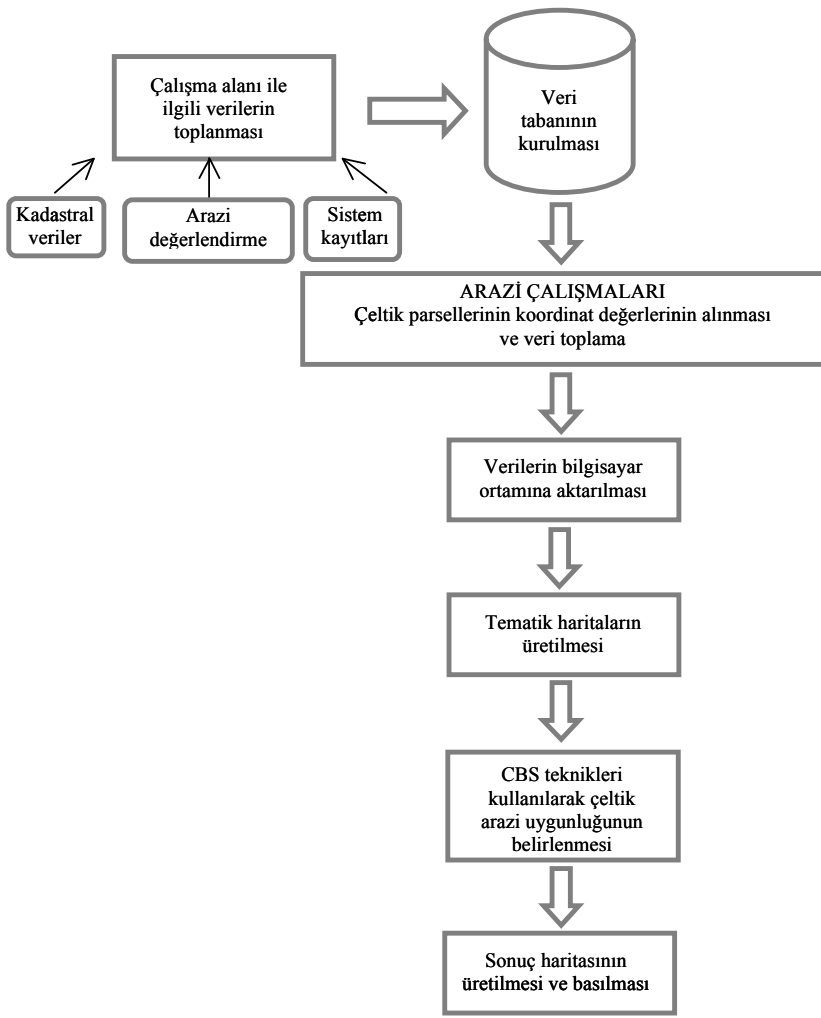

Șekil 2. Çalıșmanın akıș diyagramı

Figure 2-. Flow diagram of study

endeksleri așağıdaki formüle göre (Eșitlik 1) analiz edilmiș ve fiziksel haritalama birim endeksi (FHBE) hesaplanmıștır.

FHBE=ÜTTxATTxEGMxDERxKIRxVRTXDRNxYTAxTUZxOMxpH (1)

Eșitlik 1' de verilen formülde; ÜT: Üst toprak tekstürü, ATT: Alt toprak tekstürü, EGM: Eğim, DER: Derinlik, KIR: Kireç, VRT: Vertik özellik, DRN: Drenaj, YTA: Yüzey tașllığı, TUZ: Tuzluluk, OM: Organik madde, $\mathrm{pH}$ : $\mathrm{pH}$ değerini ifade etmektedir. Hesaplanan bu endeks değerleri (FAO, 1977) sınıflama sistemine göre değerlendirilmiștir (Çizelge 1). Calıșmada çeltik arazilerinin hangi uygunluk sınıfı içinde kaldığı belirlenerek alansal ve oransal değerler belirlenmiștir. İklim șartları değerlendirildiğinde çalıșma alanının çeltik yetiștiriciliği açısından çok uygun olduğu, görülmektedir. Çalıșma alanındaki çeltik üreticileri çeltik yetiștiriciliği konusunda yeterli bilgi ve tecrübeye sahip çiftçilerden olușmaktadır.

\section{BULGULAR VE TARTIȘMA}

Çalıșma alanı içinde koordinat değerleri alınarak kadastro paftası üzerine ișlenmiș olan çeltik arazilerinin yüzölçümü toplam 3545,63 da' dır. Çizelge 2 incelendiğinde çalıșma alanında çeltik arazi kullanım türlerinin \% 38,89'u çok uygun - S1, \% 26,66's az uygun - $\$ 3$ ve \% 34,45' inin N1- geçici uygun olmayan alanlar üzerinde olduğu tespit edilmiștir. Bașka bir değerlendirme ile çalıșma alanındaki çeltik arazilerinin \% 65,55' inin çok uygun ve az uygun kabul edilebilir sınıflar içinde olduğu \% 34,45 gibi önemli bir kısmının ise yanlıș araziler üzerinde bulunduğu görülmektedir. Farklı araștııcıların yapmıș oldukları çalıșmalarda da buna benzer değerler bulunmaktadır. Dengiz (2013) Çankırı, Kızılırmak'ta topoğrafik ve toprak koșullarına göre yaptığı değerlendirmede çeltik arazi kullanım türünün \% 34' ünün uygun olmayan araziler üzerinde olduğunu saptamıștır. Saygın (2013) Samsun Bafra'da yaptığı çalıșmada ise çeltik arazilerinin \% 20' sinin uygun olmayan alanlar üzerinde olduğunu belirlemiștir. Mustafa vd., (2011) Hindistan, Agra ve Uttar'da çeltik arazilerinin \% 50' ye yakınının (SZ-orta uygun) araziler üzerinde olduğunu bildirmișlerdir. Isitekhale vd., (2013) Nijerya, Anegbette' de yürüttükleri çalıșmalarında bu bölgede çeltik tarımı yapılan alanların çeltik yetiștiriciliğine uygun olmadığını tespit etmișlerdir.

Celtik parsellerin uygunluk sınıflamasına ait harita Șekil 3' de verilmiștir. Çalıșmada çeltik arazilerinin S1, $\mathrm{S} 3$ ve $\mathrm{N} 1$ sınıflarında bulunmasında en temel etken söz konusu arazilerin yetenek, verimlilik, yüzey topografyası ve jeolojik özellikleridir. Çalıșma alanı topraklarının yüzey morfolojisi ve yüzey coğrafyası çeltik yetiștiriciliği için çok uygundur. Bu nedenle bütün sınıflarda yüzey topografyası kaynaklı kısıtlayıcı etmen bulunmamaktadır. SI (çok uygun) sınıflarını olușturan araziler; eğim değeri \% 0-2 olan, toprak derinliğinin derin olduğu, orta derecede drenaj problemi olan, yüzey tașllığı olmayan, organik maddece zengin, alt toprak tekstürü ince, $\mathrm{pH}$ değerinin çeltik bitkisi için uygun aralıkta olduğu, tuzsuz, kireçsiz, vertik özellikler gösteren alanlardan oluștuğu tespit edilmiștir.

Çizelge 1. Fiziksel haritalama birim endeksi (FHBE) ve arazi uygunluk sınıfları (FAO 1977)

Table 1. Physical mapping unit index (PMUI) and land suitability classes for (FAO, 1977)

\begin{tabular}{lll}
\hline Fizikse Haritalama Birim Endeksi (FHBE) & Sembol & Uygunluk Sınıfı \\
\hline $0,90-1,00$ & $\mathrm{~S} 1$ & Çok uygun \\
$0,75-0,89$ & $\mathrm{~S} 2$ & Orta uygun \\
$0,50-0,74$ & $\mathrm{~S} 3$ & Az uygun \\
$0,25-0,49$ & $\mathrm{~N} 1$ & Uygun değil (Geçici) \\
$0,00-0,24$ & $\mathrm{~N} 2$ & Uygun değil (Sürekli) \\
\hline
\end{tabular}


Çizelge 2. Arazilerin çeltik yetiștiriciliğine uygunluk sınıları Table 2. Arazilerin çeltik yetiștiriciliğine uygunluk sınıfları

\begin{tabular}{llll}
\hline Arazi kullanım türü & Sınıf & Alan (da) & Oran (\%) \\
\hline Celtik & S1 & 1379,23 & 38,89 \\
Celtik & S3 & 945,28 & 26,66 \\
Çeltik & N1 & 1221,12 & 34,45 \\
Toplam & & 3545,63 & 100,00 \\
\hline
\end{tabular}

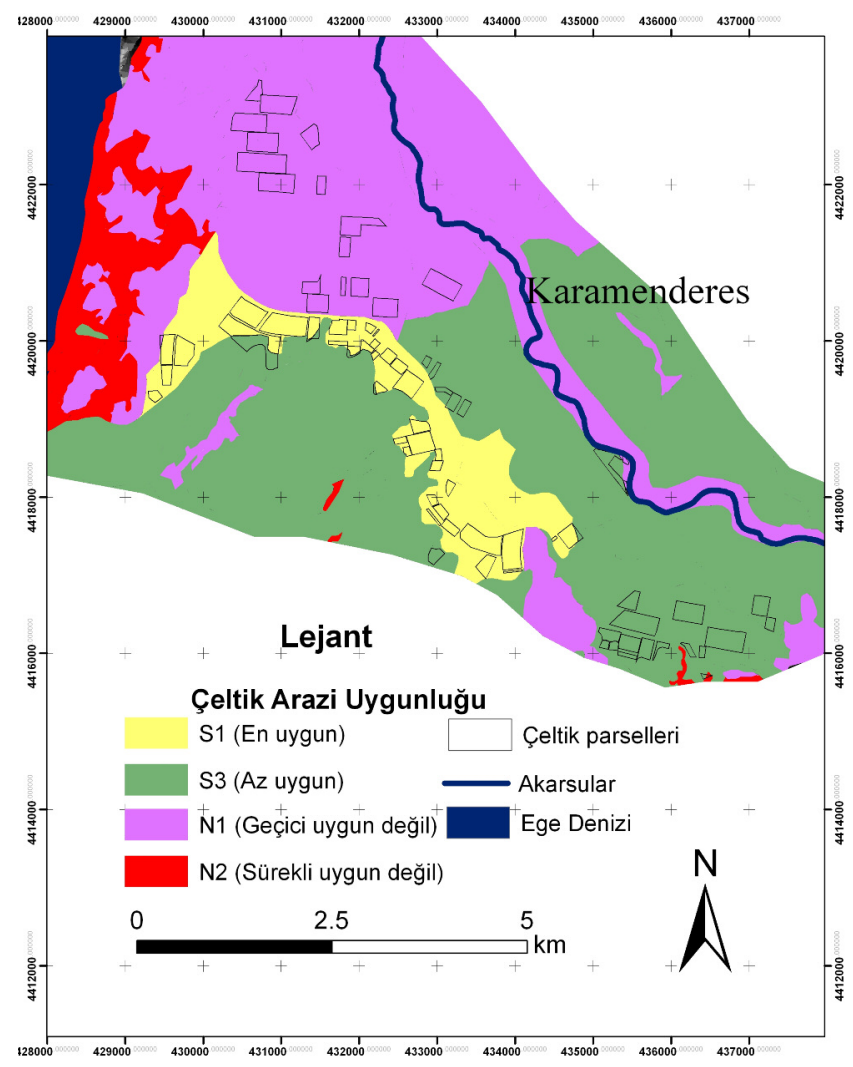

Șekil 3. Çeltik parsellerinin uygunluk sınıflaması

Figure 3. Suitability classification of rice parcel's

Çalıșma alanında bu bölümler Vertisol ordosunun Typic Endoaquerts ve Ustic Haplusterts alt grubuna ait topraklar üzerinde bulunmaktadır Uygunluğu daha yüksek olan bu alanlar jeolojik yapı içinde Karamenderes Nehri' ne daha uzak bölgede olușmuș ve çevresine göre daha çukur topografya bulunan alanlardır (Everest 2015). Çalıșma alanında bulunan S3 (az uygun) ve N1 (geçici uygun değil) alanlarında ise SI (çok uygun) alanlarına göre daha fazla kısıtlayıcı etmen bulunmaktadır. Bu alanlarda özellikle yüzey toprağının ve yüzey altı toprağının tekstürel özellikleri en baskın faktördür. Bu kısıtlayıcı etmenin yanı sıra organik madde miktarının azlığı ile yüzey ile yüzey altı topraklarının $\mathrm{pH}$ değerleri (yüzey altında S3 alanlarında 8,15-8,20, N:1 alanlarında 8,50 civarında olması), kısıtlayıcı faktörleri arttırmakta ve kademeli olarak S3 ve N1 sınıflarının olușmasına neden olmaktadır. (Everest, 2015; Everest ve Özcan, 2015). Jeolojik olarak bu alanlar Karamenderes Nehri' ne daha yakın kısımlarda oluștuğu için su tutma kapasiteleri düșük, geçirgenliği yüksek ve kaba tekstürlü topraklardır (Everest, 2015). Uygunluğu daha düșük olan S3 ve N1 alanlarında organik madde miktarının yükseltilmesi gerekmektedir. Organik madde ilavesi bu alanlarda taneciklerin birbirine bağlanmasını teșvik edeceği gibi verimlilik parametrelerini de arttıracaktır. Organik madde ilavesinin çeltik yetiștiriciliğinde uzun yıllar içinde olumlu verimlilik özellikleri sağladığı çeșitli araștırıcılar tarafından bildirilmiștir. (Prasad ve Sinha 2000; Alagöz vd., 2006). Bu alanlarda pH değerinin çeltik yetiștiriciliği için uygun aralığa ( $\mathrm{pH}$ 5,5-7,5) getirilebilmesi için (Sürek, 2002) kükürt uygulaması yapılmalı ve kireçli gübrelemeden kaçınılarak sülfatlı gübreler tercih edilmelidir. Yapılabilecek bu amenajman faaliyetleri ile S3 ve N1 sınıfındaki alanlar gelecek dönemlerde daha üst sınıflara (S2 ve N1 sınıflarına) dönüșebileceği düșünülmektedir. Bu değișim ve dönüșümün sağlanması ile toprakların optimum kullanılması ve verim kayıplarının azalması beklenmektedir.

\section{SONUÇLAR}

Bitkisel üretimde optimum verimi almak için uygulanması gereken yöntemlerden biride uygun bitkilerin uygun araziler üzerinde yetiștirilmesidir. Çalıșma alanında yanlıș alanlarda tesis edilen çeltik bitkisi üreticilere beklenmeyen problemler çıkarmaktadır. Çalıșma alanında N1 sınıfında bulunan arazilerdeki temel problemler, toprakların kaba bir bünyeye sahip olması, geçirgenliğinin fazla, su tutma kapasitesi ve organik madde miktarının düșük olması ve yüzey altında yüksek pH değerlerine sahip olmasıdır. Çalıșma alanında (N1 alanlarında), düșük su tutma kapasitesi ve geçirgenliği yüksek olan kaba bünyeli çeltik tavalarından su, profilin alt horizonlarından yanlara doğru hareket etmekte ve komșu parsellerde farklı ürün yetiștiren üreticilerin, çeltik parselinden gelen fazla sudan zarar görmesine neden olmaktadır. Tava sulama sistemlerinin kritik yanlarından biride derine sızmaların minimum düzeye indirilememesidir (Temizel, 2012). Verburg vd., (2009), arazi kullanım türlerinin ișlevinin gözlenmesi ve izlenmesi çalıșmalarında sosyoekonomik yapının gözlemlenmesi ve analiz edilmesi gerektiğinden bahsetmișlerdir. Dolayısıyla 
arazi kullanım türlerinin analizi ve izlenmesi sadece teknik bir gözlem olmayıp aynı zamanda sosyolojik olgularında kendi içinde değerlendirildiği bir süreçtir. Özellikle N1 alanlarında yapılan üretim üreticiler arasında sosyolojik problemlere neden olmaktadır.

Çalıșmada (S1 çok uygun) olan alanlar ağır bünyeli, su tutma kapasitesi yüksek, geçirgenliği az, organik maddece daha zengin, uygun $\mathrm{pH}$ aralığında bulunan, orta derecede drenaj problemi olan ve verimlilik özellikleri yüksek olan Typic Haplusterts ve Ustic Endoaquents sınıfları üzerindedir. Vertisoller dıșında yapılan üretimlerde (S3 ve N1 alanları) tarımsal üretim masrafları bir kademe daha artmakta ve istenilen verimi almak için daha fazla kültürel ișlem yapılmasına neden olmaktadır. Typic Ustifluvents topraklarının üzerinde bulunan S3 ve N1 alanlarında üretim yapan üreticiler, birim alandan istenilen ürünü almak için S1 alanlarında üretim yapanlara göre daha fazla kimyevi gübre kullanmaktadır. Bu durum hem gübre hem de ișçilik masraflarını arttırmaktadır.

Celtik parsellerinin ruhsatlandırımasında çeltik yetiștiriciliğine uygun, verim kayıplarının minimum düzeyde yașanabileceği ve diğer parsellerden kaynaklanabilecek zararların az düzeyde olduğu alanların seçilmesi sürdürülebilirliğin sağlanabilmesi için gerekmektedir. Bu șekilde yönlendirilebilecek arazi kullanım planlaması uzun zaman dilimi içinde sürdürülebilir koșulların ve sosyo-ekonomik dengenin tesis edilmesi konusunda etkili olacaktır.

Mevcut koșullarda çeltik tarımı yapılan alanların çevresel etkileri dikkate alındığında önemli sorun olușturabilecek konumda oldukları görülmektedir. Alt havza membasında yer alan parseller havzasının önemli bir kısmına etki yapabilecek konumda yer almaktadırlar. Özellikle tavalardaki sular Karamenderes Nehri' ne deșarj edilmektedir. Bu nehir ovadaki en önemli sulama suyu kaynağıdır. Sedde içindeki parsellerin tamamı ve nehre yakın sulama sistemine uzak konumdaki bazı parsellerde bu suyu sulama suyu olarak kullanmaktadır. Çeltik atık sularının nehir suyuna karıșması gübre ve ilaç kalıntılarını beraberinde getirmektedir. Ovada görülen bazı beklenmeyen hastalıkların nedeninin bu tarımsal faaliyetlerden olușabileceği gerçeği dikkate alınmalıdır. Çalıșmada değerlendirilen veriler doğrultusunda alt havzanın kuzeyinde (Karamenderes Deltası) ruhsatlandırma yapılması daha uygun bulunmuștur.

\section{KAYNAKLAR}

Alagöz Z, Yılmaz E, Öktüren F (2006). Organik materyal ilavesinin bazı fiziksel ve kimyasal toprak özellikleri üzerine etkileri. Akdeniz Üniversitesi Ziraat Fakültesi Dergisi 19.2 (2006): 245-254

Anonim (2015). Ezine İlçe Gıda Tarım ve Hayvancılık Müdürlüğü brifing raporu.

Atalay i (1991). Toprak Coğrafyası, Ege Üniversitesi basımevi, Ders kitabı, Bornova İzmir

Badawi A T (2004). Rice-based production systems for food security and poverty alleviation in The Near- East and North Africa: New challenges and technological opportunities. FAO rice conference Rome, Italy, 12-13 February.

Dengiz O (2013). Land suitability assessment for rice cultivation based on GIS modeling, Turkish Journal of Agriculture and Forestry, (2013) 37: 326-334.

Ekinci H (1990). Türkiye genel toprak haritasının toprak taksonomisine göre düzenlenebilme olanaklarının Tekirdağ bölgesi örneğinde araștırılması, C..Ü. Fen Bilimleri Enstitüsü, Doktora Tezi.

Everest T (2015). Truva Tarihi Milli Parkı arazilerinin detaylı toprak etüt ve haritalanması ile arazi değerlendirmesi, Çanakkale Onsekiz Mart Üniversitesi, Fen Bilimleri Enstitüsü, Doktora Tezi. 203 sf

Everest T, Özcan H (2015). Karamenderes Ovası, Truva bölgesi sağ sahil fluviyal topraklarının sınıflandırılması, Toprak Su Dergisi, 2015,4 (2): (21-29)

FAO (1977). A framework for land evaluation. International institute for land reclamation and improvment/ILRI publication:22, wageningen, The Netherlands. 87p.

Isitekhale, H H E, Aboh S. I, Ekhomen F E (2013). Soil suitability evaluation for rice and sugarcane in lowland soils of Anegbette, Edo State, Nigeria. Int. J. Eng. Sci 3.5 (2013): 54-62.

Kayan I (2000). The water supply of Troia. Studia Troica, verlag philipp von zabern, mainz am rhein, pp.135-144.

Kondo M, Aguilar A, Abe J, Morita S (2000). Anatomy of nodal roots in tropical upland and lowland rice varieties. Plant Prod. Sci., 437-445.

Maddahi Z, Jalalian A, Zarkesh, M M K, Honarjo N (2014). Land suitability analysis for rice cultivation using multi criteria evaluation approach and GIS. European Journal of Experimental Biology, 4(3), 639-648.

Meral R, Temizel E K (2006). Celtik tarımında sulama uygulamaları ve etkin su kullanımı. KSÜ. Fen ve Mühendislik Dergisi, 9(2).

Mustafa A A, Singh M, Sahoo R N, Ahmed N, Khanna M, Sarangi A, Mishra A K (2011). Land suitability analysis for different crops: A multi criteria decision making approach using remote sensing and gis. Researcher, 3(12), 1-24.

Özșahin E (2016). CBS kullanılarak çeltik tarımı için arazi uygunluk değerlendirmesi: Hayrabolu deresi havzası (Trakya Yarımadası) örneği. Tarım Bilimleri Dergisi, 22 (2016) 295-306. 
Peșkircioğlu M, Torunlar H, Alsancak S B, Özaydın K A, Mermer A, Șahin M, Tugaç M G, Aydoğmuș $O$, Emeklier, $Y$, Yıldırım Y E, Kodal S (2013). Türkiye'de çeltik (Oryza sativa L.) yetiștirmeye uygun potansiyel alanların coğrafi bilgi sistem teknikleri ile belirlenmesi, Tarla Bitkileri Merkez Araștırma Enstitüsü Dergisi, 2013, 22 (1): 20-25.

Prasad B, Sinha, S K (2000). Long-term effects of fertilizer and organic manures on crop yields, Nutrient balance and soil properties in rice-wheat cropping system in Bihar. pp: 105- 119 in long-term soil fertility experiments in rice-wheat cropping systems. rice-wheat consortium paper series 6. New Delhi, INDIA.

Samanta S, Pal B, Pal D . (2011). Land suitability analysis for rice cultivation based on multi-criteria decision approach through GIS. International Journal of Science \& Emerging Technologies, 2(1).
Saygın, F (2013). Coğrafi bilgi sistem modellemesi ile arazi uygunluk sınıflarının belirlenmesi. Ondokuz Mayıs Üniversitesi, Fen Bilimleri Enstitüsü yüksek lisans tezi.

Seck P A, Diagne A, Mohanty S, Wopereis M C S (2012). Crops that feed the world 7: Rice food security, 2012, 4, 7-24.

Sürek (2002). Çeltik tarımı, Hasad yayıncılık, İstanbul.

Temizel K E (2012). Tava sulama yönteminin planlanması ve çiftçiye adaptasyonu sağlayabilecek grafiksel bir yaklașım, Tekirdağ Ziraat Fakültesi Dergisi, 2012 (9) 26-32.

Tüik (2015). Türkiye İstatistik Kurumu, temel tarımsal istatistikler, 2015. www.tuik.gov.tr

Verburg P H, Steeg J, Veldkamp A, Willemen L (2009). From land cover change to land function dynamics: A major challenge to improve land characterization, Journal of Environmental Management, 90: 1327-1335. 